\title{
Strength Properties of Untreated Coal Bottom Ash as Cement Replacement
}

\author{
Noraziela Syahira Baco ${ }^{1}$, Shahiron Shahidan ${ }^{2 *}$, Sharifah Salwa Mohd Zuki ${ }^{2}$, Noorwirdawati \\ Ali $^{2}$, Mohamad Azim Mohammad Azmi ${ }^{3}$ \\ 1 Jing sheng Construction \& Engineering Sdn Bhd Lot PT807, No.13, Jalan 20, Kampung Cheras Baru 56100 Kuala Lumpur, MALAYSIA \\ ${ }^{2}$ Department of Civil Engineering, Faculty of Civil \& Environmental Engineering, Universiti Tun Hussein Onn Malaysia, 86400, Batu Pahat, \\ Johor, MALAYSIA \\ ${ }^{3}$ Center for Diploma Studies, Department of Civil Engineering, Universiti Tun Hussein Onn Malaysia, Pagoh Higher Education HUB, KM1, \\ Jalan Panchor, 84600 Pagoh Muar Johor, MALAYSIA \\ *Corresponding authors: shahironshahidan@gmail.com
}

SUBMITTED 15 July 2019 REVISED 4 November 2019 ACCEPTED 20 January 2020

\begin{abstract}
Coal Bottom Ash (CBA) is a mineral by-product of thermal power plants obtained from the combustion of coal. In many countries, CBA wastes are identified as hazardous materials. The utilization of CBA can help in alleviating environmental problems; thus, this research was carried out to explore the possibility of its use as cement replacement in concrete manufacturing. Presently, In Malaysia, research that concerns about the use of CBA as cement replacement is very limited. Therefore, this study was aimed to investigate the properties of CBA as cement replacement and to identify the optimum percentage of untreated CBA as cement replacement. The CBA used in this study were taken from the Tanjung Bin power plant. In this research, the amount of CBA in the concrete mixture varied from $20 \%$ to $40 \%$ to replace cement. The properties of concrete containing CBA as cement replacement was examined through slump test, sieve analysis, concrete compressive strength test and splitting tensile strength test. The compressive strength test and splitting tensile strength test were performed at 7 and 28 days of curing time. Based on this research, it can be concluded that the optimum percentage of CBA as cement replacement is $25 \%$ for a curing time of both 7 and 28 days with the concrete compression strength of $45.2 \mathrm{MPa}$ and $54.6 \mathrm{MPa}$, respectively. Besides, the optimum percentage for tensile strength is also at 25\% CBA for a curing period of both 7 and 28 days with the tensile strength of $2.91 \mathrm{MPa}$ and $3.28 \mathrm{MPa}$, respectively.
\end{abstract}

KEYWORDS Coal Bottom Ash; Cement Replacement; Untreated; Concrete Material; Power Plant

(C) The Author(s) 2020. This article is distributed under a Creative Commons Attribution-ShareAlike 4.0 International license.

\section{INTRODUCTION}

One of the most important sources of energy is coal, which is fueling almost $40 \%$ of electricity worldwide. In Malaysia, some power plants use coal as a raw material to generate electricity since 1988. One of the thermal power plants byproducts is the Coal Bottom Ash (CBA) that faces an increasing production running into hundreds of thousand tones in Malaysia. CBA is produced due to the presence of rock detritus in the fissures of the coal seams. In the combustion process, the combustible materials were burned; meanwhile, the incombustible material such as rock detritus then resulted in CBA. It is one of the renowned industrial wastes produced at the bottom of coal furnaces. It is originated from agglomerated ash particles that are not lighter and finer to be found in the flue gasses.

CBA extracted from the boiler flue gases is called fly ash (FA) and the coarser part collected at bottom of the furnace is called CBA. Degree of pulverization of coal, firing temperature in the furnace, and type of furnace affect the properties of CBA (Singh and Siddique, 2016). The fly ash has been widely used in the cement industry but the bottom ash is still not largely utilized in Malaysia (Marto and Tan, 2016). The CBA was disposed to the landfills without any other commercial usage (Abubakar and Baharudin, 2012). In many countries, CBA was identified as hazardous materials. Therefore, safe, innovative, 
environmentally friendly, sustainable, and economical solutions to recycle these industrial by-products are required.

The replenishment of CBA that has different mineralogical and physical characteristics than cement in the concrete mixture may have a remarkable effect on the concrete mechanical properties compared with the plain concrete in the hardened state (Khan and Ganesh, 2016). The use of waste materials such as CBA as cement supplementary material in concrete can result in alleviating the environmental problems and cost savings (Sua-Iam and Makul, 2014). By using CBA, it is possible to produce lightweight concrete with density varies from 1560-1960 $\mathrm{kg} / \mathrm{m}^{3}$ and compressive strength varies from 20$40 \mathrm{~N} / \mathrm{mm}^{2}$ at 28 days (Bai, Darcy and Basheer, 2005). Concrete made from CBA exhibited a reduced drying shrinkage in comparison with that of the control samples (Cai, Ghafoori and Yuzheng, 1998).

Due to increased demand for mixing water, Bottom Ash (BA) mixture might display a much higher degree of bleeding than the control concrete. Besides, it has high fire resistance for protection against fire. Those materials that retain a large quantity of water are more desirable since when they are exposed to fire, part of this water evaporates and it is transported from the fire exposed surface to the interior of the material, where the water cools and condenses again (García Arenas et al., 2011).

The porosity of hydrated paste influenced the strength development of concrete which is controlled by water-cement ratio and the presence of bond cracks at the interface of aggregate and hydrated paste. Besides, the strength of individual constituent material of concrete also has influenced the strength of the concrete mixture. The compressive strength of CBA concrete mixture was developed in a comparable manner to that of control concrete mixture (Singh and Siddique, 2016). Besides, the compressive strength of CBA decreased as CBA content in concrete increased (Andrade, Rocha and Cheriaf, 2009).
The tensile strength of CBA concrete progresses in similar to normal concrete. Besides, when compared to the concrete compressive strength of, CBA had more influence on the development of split tensile strength. CBA concrete containing $50 \%$ CBA showed a maximum increase of $11.01 \%$ in splitting tensile strength (Singh and Siddique, 2016). There was no change in split tensile strength and it decreased considerably with increase in bottom ash content if the sand replacement used up to $10 \%$. If the percentage of cement content was not changed, the tensile strength decreased with increase in CBA content (Cai, Ghafoori and Yuzheng, 1998). This study was emphasized to determine the properties (compressive and tensile strength) the optimum percentage of untreated CBA as cement replacement.

\section{METHODS}

\subsection{Materials}

Ordinary Portland Cement (OPC) was used in this research. Fine aggregate for the concrete mixture was clean, hard and well graded. Therefore, in this study, the fine aggregate that passed through 2 $\mathrm{mm}$ sieve was selected. Freshwater and tap water was used in this research. The Coal Bottom Ash (CBA) was obtained from Tanjung Bin power plant in Pontian, Johor as shown in Figure 1. The quantity of CBA in the concrete mixture was made in several variations i.e. $0 \%$ (as a control), $20 \%$, $25 \%, 30 \%, 35 \%$, and $40 \%$ to find the optimum percentage of CBA as a cement replacement.

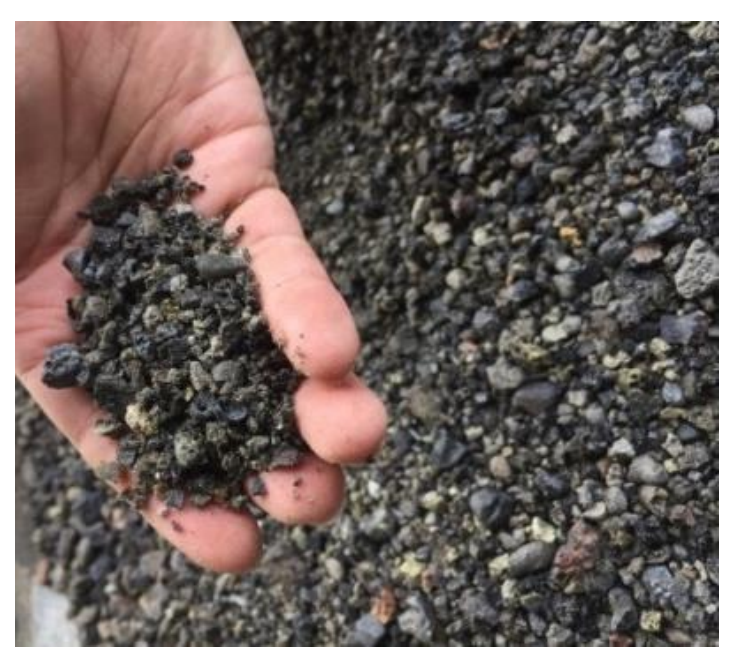

Figure 1. Coal Bottom Ash 


\subsection{Sample preparation}

36 samples were prepared for each compressive strength test and split tensile strength test as summarize in Table 1 . The tests were conducted at 7 and 28 days of curing time. Water content, cement content, and aggregate content for this research were determined using standard mix design concrete that is DOE methods. Table 2 shows the concrete mix design used in this research

For this research, the slump test was performed to control the consistency of the fresh concrete made in the laboratory. In order to prevent water loss in the concrete samples, the water curing method was applied as shown in Figure 2. In this type of curing, all of the samples were soaked in the water tank for 7 days and 28 days.

\subsection{Compressive Strength Test}

The compressive strength was determined in accordance with BS EN (196-1) and BS 1881: Part 116: 1983 (Method of determination of compressive strength of concrete cubes). For this research, the dimension of each concrete cube used was $100 \mathrm{~mm}$ x $100 \mathrm{~mm} \times 100 \mathrm{~mm}$. All the concrete cube specimens were taken for the compressive test at 7 and 28 days of curing time.

\subsection{Splitting Tensile Strength Test}

The specimen for splitting tensile strength test was consist of $200 \mathrm{~mm}$ height concrete cylinder with the diameter of $100 \mathrm{~mm}$. This test was carried out as specified by BS 1881: Part 117 (Testing Concrete - Method for determination of tensile splitting strength. British Standards Institute, London).

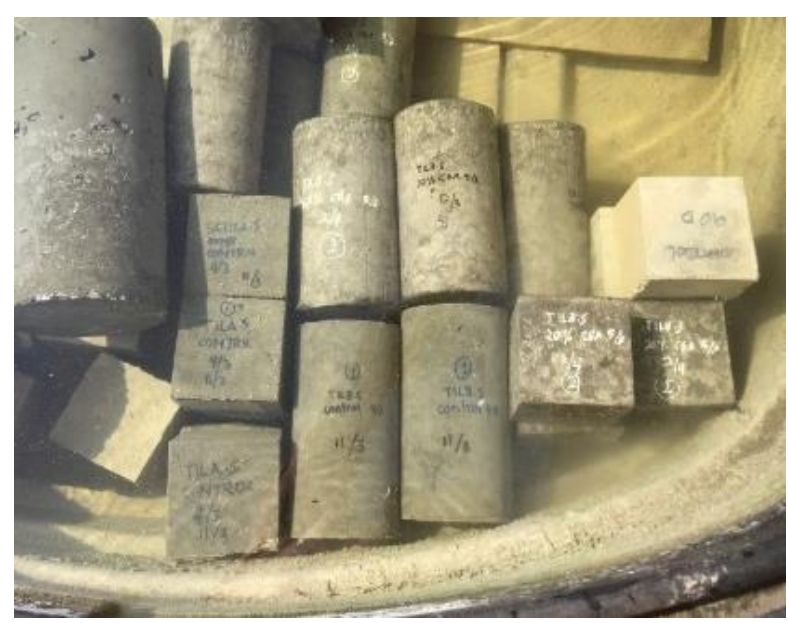

Figure 2. Curing of Concrete

Table 1. Specimen samples

\begin{tabular}{lllll}
\hline & Compression & & Tensile & \\
\hline Sample & 7 days & 28days & 7 days & 28days \\
\hline Control (0\%) & 3 & 3 & 3 & 3 \\
$20 \%$ & 3 & 3 & 3 & 3 \\
$25 \%$ & 3 & 3 & 3 & 3 \\
$30 \%$ & 3 & 3 & 3 & 3 \\
$35 \%$ & 3 & 3 & 3 & 3 \\
$40 \%$ & 3 & 3 & 3 & 3 \\
\hline & 18 & 18 & 18 & 18 \\
\hline Total & 72 & & & \\
\hline
\end{tabular}

Table 2. Concrete mix design

\begin{tabular}{llllll}
\hline $\begin{array}{l}\text { Percentage } \\
(\%)\end{array}$ & Cement $(\mathrm{kg})$ & Water $(\mathrm{kg} / \mathrm{L})$ & $\begin{array}{l}\text { Fine aggregate } \\
(\mathrm{kg})\end{array}$ & $\begin{array}{l}\text { Coarse } \\
\text { aggregate }(\mathrm{kg})\end{array}$ & $\begin{array}{l}\text { Coal Bottom } \\
\text { Ash }(\mathrm{kg})\end{array}$ \\
\hline 0 & 3.91 & 1.76 & 4.79 & 11.16 & 0.00 \\
20 & 3.12 & 1.76 & 4.79 & 11.16 & 0.78 \\
25 & 2.92 & 1.76 & 4.79 & 11.16 & 0.98 \\
30 & 2.73 & 1.76 & 4.79 & 11.16 & 1.17 \\
35 & 2.53 & 1.76 & 4.79 & 11.16 & 1.37 \\
40 & 2.34 & 1.76 & 4.79 & 11.16 & 1.56 \\
\hline
\end{tabular}




\section{RESULTS AND DISCUSSION}

\subsection{Slump Test}

A Slump test was carried out to determine the flowability of the concrete. Figure 3 shows the result of the slump test in the concrete mixture containing a different percentage of CBA.

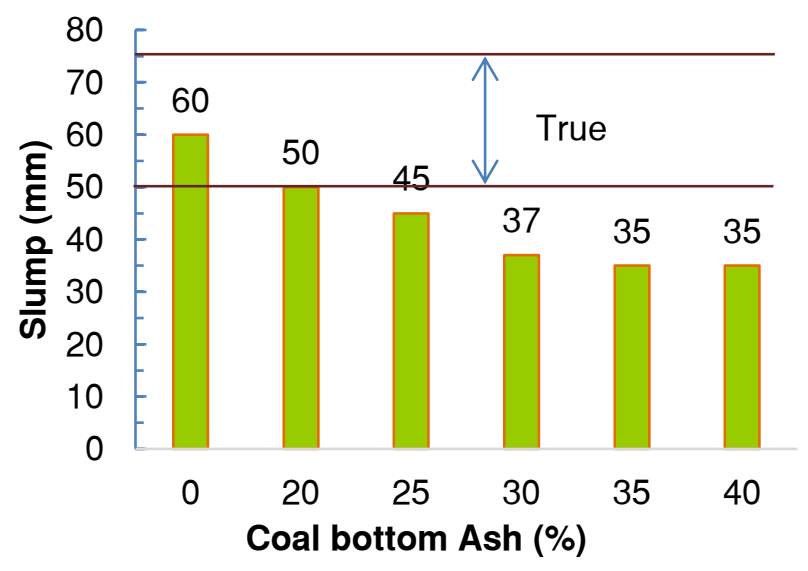

Figure 3. Relationship between slump and concrete containing a different percentage of CBA

From the result in Figure 3, there is a gradual decreasing of slump between control specimen and concrete containing $35 \%$ of CBA. This indicated that the workability of concrete is decreasing. The slump remains constant between $35 \%$ and $40 \%$ which indicated the lowest slump among the different percentages of CBA in concrete.

The workability of concrete containing CBA decreases as the CBA content increases due to increasing particle friction. Rough textured, irregular shaped and porous particles of CBA lead to particle friction (Singh and Siddique, 2016).

\subsection{Density of Concrete}

The density of concrete was examined at 7 and 28 days. Table 3 and Table 4 show the density of concrete containing CBA as cement replacement.

\subsection{Compressive Strength}

Figure 4 shows the details of the concrete compressive strength that contains different percentages of CBA in 7 and 28 days. The data presented in Figure 4 is an average result of 3 concrete cubes. Figure 4 shows that concrete cube with $25 \%$ of CBA produces the highest compression strength compared to others. The average compression strength at 7 and 28 days is $45.2 \mathrm{MPa}$ and was 54.6MPa, respectively. Based on the compressive strength test result, it can be concluded that the optimum percentage of CBA as cement replacement is $25 \%$. The use of CBA in the concrete mixture as cement replacement can reduce the usage of cement. It is suitable to be used in the construction industry.

\subsection{Tensile Strength}

Figure 5 shows the result of the splitting tensile strength test of the concrete with different percentages of CBA at 7 and 28 days of curing time. The value presented in Figure 5 is an average of 3 concrete cylinders.

Figure 5 depicts that the optimum percentage CBA is $25 \%$ of the cement, with the tensile strength of $2.91 \mathrm{MPa}$ (at the 7 days of curing time) and $3.28 \mathrm{MPa}$ (at the 28 days of curing time). At 7 days of curing time, the second-highest concrete tensile strength was achieved by concrete containing $20 \%$ CBA followed by $35 \%$, 30\% and $40 \%$ CBA concrete with tensile strength of 2.29 $\mathrm{MPa}, 2.09 \mathrm{MPa}, 1.93 \mathrm{MPa}$, and $1.85 \mathrm{MPa}$. The similar result was shown at the splitting tensile test at 28 days. The quantity of CBA in the concrete mixture that produce the tensile strength from the highest to the lowest in a row is $25 \%, 20 \% 35 \%, 40 \%$ and $30 \%$ with the tensile strength of $3.28 \mathrm{MPa}, 3.2 \mathrm{MPa}, 2.96 \mathrm{MPa}, 2.6 \mathrm{MPa}$, and $2.21 \mathrm{MPa}$, respectively. Normally the range for tensile strength is about $5-8 \%$ of compressive strength

As for the conclusion, based on the tensile strength test result, the optimum percentage of CBA as cement replacement is $25 \%$. The use of CBA in concrete as cement replacement can help to maintain the sustainable use of resource and it is suitable to be used in the construction industry. Besides, by using waste material which is CBA as cement replacement can be an alternative solution to achieve environmental conservation 
Table 3. Density of concrete containing CBA as cement replacement at 7 days

\begin{tabular}{llll}
\hline Percentage of CBA (\%) & $\begin{array}{l}\text { Volume of concrete } \\
\text { cube }\left(\boldsymbol{m}^{\mathbf{3}}\right)\end{array}$ & $\begin{array}{l}\text { Mass of concrete } \\
\text { cube }(\boldsymbol{k g})\end{array}$ & $\begin{array}{l}\text { Density of concrete } \\
\left(\times \mathbf{1 0}^{\mathbf{3}} \mathbf{k g} / \mathbf{m}^{\mathbf{3}}\right)\end{array}$ \\
\hline 0 & 0.001 & 2.45 & 2.5 \\
20 & 0.001 & 2.42 & 2.4 \\
25 & 0.001 & 2.40 & 2.4 \\
30 & 0.001 & 2.41 & 2.4 \\
35 & 0.001 & 2.43 & 2.4 \\
40 & 0.001 & 2.42 & 2.4 \\
\hline
\end{tabular}

Table 4. Density of concrete containing CBA as cement replacement at 28 days

\begin{tabular}{llll}
\hline Percentage of CBA (\%) & $\begin{array}{l}\text { Volume of concrete } \\
\text { cube }\left(\boldsymbol{m}^{\mathbf{3}}\right)\end{array}$ & $\begin{array}{l}\text { Mass of concrete } \\
\text { cube }(\boldsymbol{k g})\end{array}$ & $\begin{array}{l}\text { Density of concrete } \\
\left(\times \mathbf{1 0}^{\mathbf{3}} \mathbf{k g} / \mathbf{m}^{\mathbf{3}}\right)\end{array}$ \\
\hline 0 & 0.001 & 2.45 & 2.5 \\
20 & 0.001 & 2.41 & 2.4 \\
25 & 0.001 & 2.40 & 2.4 \\
30 & 0.001 & 2.41 & 2.4 \\
35 & 0.001 & 2.42 & 2.4 \\
40 & 0.001 & 2.39 & 2.4 \\
\hline
\end{tabular}

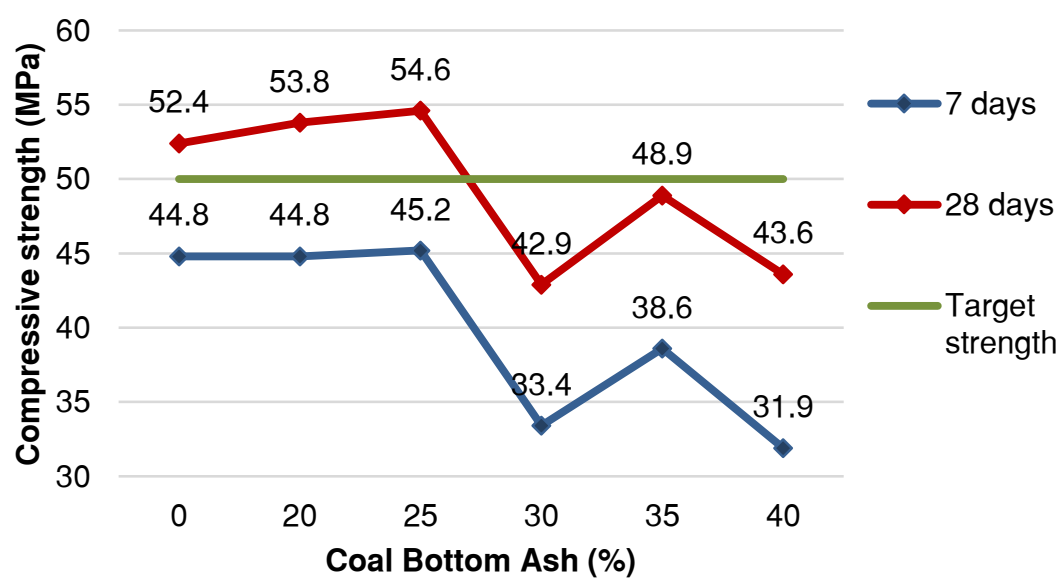

Figure 4. Compressive strength of concrete containing CBA after 7 and 28 days

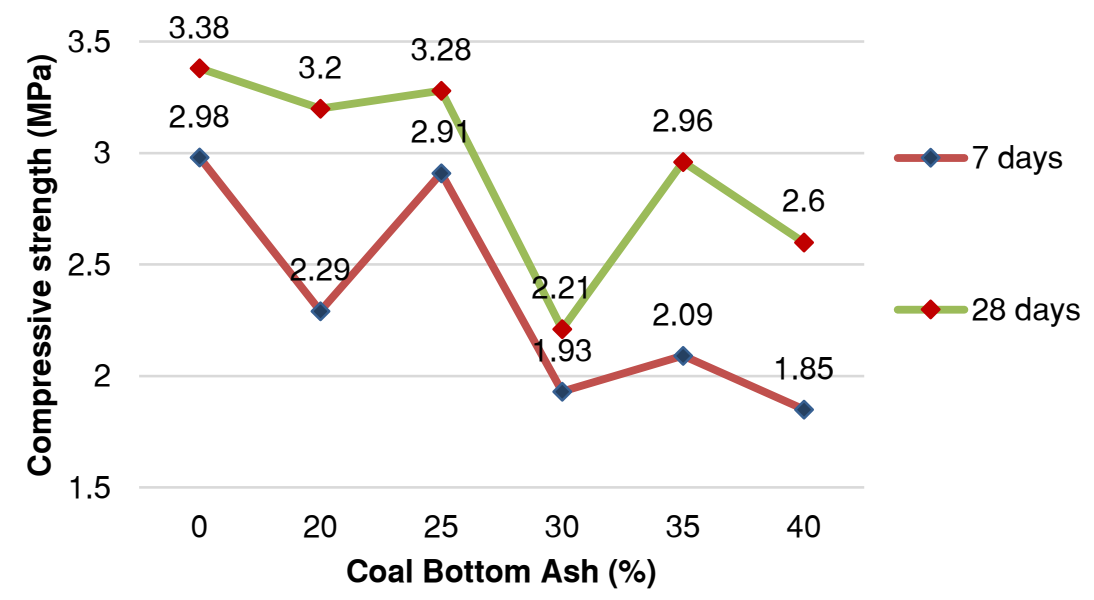

Figure 5. Tensile strength of concrete containing CBA after 7 and 28 days 


\section{CONCLUSION}

The properties of CBA concrete from this research were determined from the slump test and sieve analysis. Slump test indicates that the concrete became less workable with the increase in CBA percentage in concrete as cement replacement. Based on the results from this research, from the test on properties of the targeted constituent materials, CBA has similar particle size distribution properties to mining sand which makes them more desirable replacement materials. Besides, the slump test results show an acceptable and practical degree of workability for all the mixes. This means the percentage usage of CBA as cement replacement was designed properly and suitable for mixes.

Based on the result of this research, the optimum content of CBA as cement replacement is $25 \%$ for both compressive and tensile strength. Compressive test results showed that at the age of 28 days $20 \%$ and $25 \%$ of CBA mixes have achieved strength higher than $50 \mathrm{MPa}$. For the splitting tensile test, it can be seen that $25 \%$ of CBA as cement replacement is the optimum percentage. However, the value is still lower than their control specimen. This might due to high amount of water absorption by the high percentage of replaced materials as CBA have relatively highwater absorptions. It seems that, water cement ratio of these mixes will affect their strength greatly.

Besides, this research proved that the waste produced by Tanjung Bin power plant is suitable to be used as cement replacement. As for the conclusion, the use of CBA in concrete as cement replacement may help to reduce the use of cement and maintain the sustainable use of resource.

\section{DISCLAIMER}

The authors declare no conflict of interest.

\section{REFERENCES}

Abubakar, A.U. and Baharudin, K.S., 2012. Potential Use of Malaysian Thermal Power Plants. International Journal of Sustainable construction Engineering \&Technology, 3(2), pp.25-37.

Andrade, L.B., Rocha, J.C. and Cheriaf, M., 2009. Influence of coal bottom ash as fine aggregate on fresh properties of concrete. Construction and Building Materials, 23(2), pp.609-614.

Bai, Y., Darcy, F. and Basheer, P.A.M., 2005. Strength and drying shrinkage properties of concrete containing furnace bottom ash as fine aggregate. Construction and Building Materials, 19(9), pp.691-697.

Cai, Ghafoori, N. and Yuzheng, 1998. LaboratoryMade RCC containing Dry Bottom Ash: Part IMechanical Properties. ACI Materials Journal, 95(2).

García Arenas, C., Marrero, M., Leiva, C., SolísGuzmán, J. and Vilches Arenas, L.F., 2011. High fire resistance in blocks containing coal combustion fly ashes and bottom ash. Waste Management, 31(8), pp.1783-1789.

Khan, R.A. and Ganesh, A., 2016. The effect of coal bottom ash (CBA) on mechanical and durability characteristics of concrete. J. Build. Mater. Struct, 3, pp.31-42.

Marto, A. and Tan, C.S., 2016. Properties of Cola Bottom Ash from Power Plants in Malaysia and Its Suitability as Geotechnical Engineering Material. Jurnal Teknologi, 78(8-5), pp.1-10.

Singh, M. and Siddique, R., 2016. Effect of coal bottom ash as partial replacement of sand on workability and strength properties of concrete. Journal of Cleaner Production, 112, pp.620-630.

Sua-Iam, G. and Makul, N., 2014. Utilization of high volumes of unprocessed lignite-coal fly ash and rice husk ash in self-consolidating concrete. Journal of Cleaner Production, 78, pp.184-194. 